\title{
Response of Pigeon Pea + Bajra Intercropping Systems under Variable Crop Geometry and Plant Population Level under Rainfed Condition
}

\author{
S. G. Pandit*, N. G. Khurade, V. R. More and M. P. Jagtap \\ Department of Agronomy, Vasantrao Naik Marathwada Krishi Vidyapeeth, \\ Parbhani, 431-402, India \\ *Corresponding author
}

\section{Keywords \\ Pigeon pea, Bajra intercropping systems, Rainfed condition}

Article Info

Accepted: 08 January 2020 Available Online: 10 February 2020

\section{A B S T R A C T}

The field experiment was conducted during Kharif 2017 at the Experimental Farm, Agronomy Section, College of Agriculture, Parbhani (Maharashtra). The experiment was laid out in randomized block design with three replications. There were total 8 treatments combination consisting 3 row spacing of pigeonpea combined with 2 intra-row spacings and 2 sole cropping treatments of pigeonpea and Pearl millet in the recommended spacing of respective crops added. The intercropping system of pigeonpea + pearl millet crops was tried with row proportion of $1: 1,1: 1,1: 1,1: 1,1: 2$ and $1: 2$ in $90 \mathrm{~cm} \times 30 \mathrm{~cm}, 90 \mathrm{~cm}$ x $45 \mathrm{~cm}, 120 \mathrm{~cm} \times 30 \mathrm{~cm}, 120 \mathrm{~cm}$ x $45 \mathrm{~cm}, 150 \mathrm{~cm}$ x $30 \mathrm{~cm}$ and $150 \mathrm{~cm}$ x $45 \mathrm{~cm}$ planting geometry of pigeonpea in treatments $\mathrm{T}_{1}, \mathrm{~T}_{2}, \mathrm{~T}_{3}, \mathrm{~T}_{4}, \mathrm{~T}_{5}$ and $\mathrm{T}_{6}$ respectively. Studied planting geometry of sole treatments $\mathrm{T}_{7}$ and $\mathrm{T}_{8}$ of pigeonpea and pearl millet were $90 \mathrm{~cm} \mathrm{x}$ $20 \mathrm{~cm}$ and $45 \mathrm{~cm} \times 15 \mathrm{~cm}$ respectively. Among all the treatments of pigeonpea + Pearl millet intercropping system. The sole pigeonpea $\left(\mathrm{T}_{7}\right)$ and sole pearl millet $\left(\mathrm{T}_{8}\right)$ gives higher growth attributes. The highest PEY is observed in sole pigeonpea with planting geometry $(90 \times 20 \mathrm{~cm})\left(2073 \mathrm{~kg}\right.$ ha) which was followed by treatment $\mathrm{T}_{1}, \mathrm{~T}_{3}$ and $\mathrm{T}_{5}$ i.e. row ratio 1: $1(90 \times 30 \mathrm{~cm}), 1: 1(120 \times 30 \mathrm{~cm})$ and $1: 2(150 \times 30 \mathrm{~cm})$. Hence intra-row spacing $30 \mathrm{~cm}$ under, $120 \mathrm{~cm}$ and $150 \mathrm{~cm}$ of pigeonpea row spacing along with $1: 1,1: 1$ and 1: 2 pigeonpea + pearl millet row proportion produced higher pigeonpea equivalent yield than intra row spacing $45 \mathrm{~cm}$ in intercropping system

\section{Introduction}

Intercropping is a potentially beneficial system of crop production. It is defined as the growing of two or more crop species simultaneously in the same field during a growing season. The crops are not necessarily sown at exactly the same time and their harvest times may be quite different, but they are usually 'simultaneous' for a significant part of their growing periods. Although agricultural research originally focused on sole cropping and ignored the potential of intercropping, there has been a gradual recognition of the value of this type of cropping system. Intercropping has long been recognized as a very common practice throughout the developing tropics. 
Among pulses Pigeon pea (Cajaanus cajan L.) is one of the major grain legume crop of tropical and subtropical region and its grown predominantly under rainfed condition. Pigeon pea as soil ameliorant is known as to provide several benefits to soil in which it is grown. When pigeon pea is grown as a sole crop it is relatively inefficient because of its slow initial growth rate and loe harvest index (Willey et al., 1980) therefore it is grown as intercrop, which helps in efficient utilization of available resources for enhancing the productivity and profit. Pigeon pea is suitable for different crop like cotton, sorghum, pearlmillet, greengram, maize, soybean and groundnut for increasing production and maintaining soil fertility. The initial slow growth rate and deep root system of pigeon pea offers a good scope for intercropping with fast growing early maturing and shallow rooted crops (Ramamoorthy et al., 2004).

Pigeonpea based intercropping systems have proved sustainable in respect of yield and income with short duration intercrops of cereals, pulses and oilseed crop across diverse rainfed agro ecologies in India (Rao et al., 2003). In the scarcity zone of Maharashtra, pigeonpea is cultivated during kharif under diverse biophysical (soil and rainfall types) and socioeconomic settings, thus always risk prone due to in-season drought, particularly in shallow to medium black soils, abiotic factors often resulting in unsustainable yields and income.

Pearl millet is believed to have originated in the Sahel zone of West Africa, which extends from western Sudan to Senegal. It is now widely cultivated in different parts of the world. It is an important staple food crop in large parts of Africa, particularly in the Sudan. Pearl millet is a dual purpose crop. Its grain is used for human consumption, and its straw serves as feed for cattle. The grain of pearl millet is comparatively more nutritious than other cereal grains; its protein content is $11.31-19.32 \%$.

\section{Materials and Methods}

The field experiment conducted during 2017 was conducted at Department of Agronomy, VNMKV, Parbhani. The experimental field was leveled and well drained. The soil was clay in texture, low in nitrogen, medium in phosphorus and high in potassium and alkaline in reaction i.e. $\mathrm{P}^{\mathrm{H}}(8.2)$. Total rainfall received during crop growing season was $995.01 \mathrm{~mm}$ and distributed over 42 rainy days during the process of experimentation. The environmental conditions prevailed during experimental period was favorable for normal growth and maturity of Pigeon pea + bajra intercropping systems.

The experiment was laid out in randomized block design (RBD). There were total 8 treatments consisting 3 row spacing of pigeonpea combined with 2 intra-row spacings and 2 sole cropping treatments of pigeonpea and pearl millet in the recommended spacing of respective crops added. The intercropping system of pigeonpea + pearl millet crops was tried with row proportion of $1: 1,1: 1,1: 1,1: 1,1: 2$ and $1: 2$ in $90 \mathrm{~cm} \times 30 \mathrm{~cm}, 90 \mathrm{~cm} \times 45 \mathrm{~cm}, 120$ $\mathrm{cm} \times 30 \mathrm{~cm}, 120 \mathrm{~cm} \times 45 \mathrm{~cm}, 150 \mathrm{~cm} \times 30 \mathrm{~cm}$ and $150 \mathrm{~cm} \mathrm{x} 45 \mathrm{~cm}$ planting geometry of pigeonpea in treatments $T_{1}, T_{2}, T_{3}, T_{4}, T_{5}$ and $\mathrm{T}_{6}$ respectively. Studied planting geometry of sole treatments $T_{7}$ and $T_{8}$ of pigeonpea and pearl millet were $90 \mathrm{~cm} \mathrm{x} 20 \mathrm{~cm}$ and $45 \mathrm{~cm} \mathrm{x}$ $15 \mathrm{~cm}$ respectively. Inter row and intra row spacing of pearl millet in intercropping treatments were different i.e. $45 \mathrm{~cm} \mathrm{x} 15 \mathrm{~cm}$ for $\mathrm{T}_{1}$ and $\mathrm{T}_{2}, 60 \mathrm{~cm} \times 15 \mathrm{~cm}$ for $\mathrm{T}_{3}$ and $\mathrm{T}_{4}$, and $50 \mathrm{~cm} \times 15 \mathrm{~cm}$ for $\mathrm{T}_{5}$ and $\mathrm{T}_{6}$. Sowing was done by dibbling method on June 29th, 2017. The recommended cultural practices and preventive plant protection measures were undertaken timely. 


\section{Results and Discussion}

\section{Performance of pigeon pea}

The plant growth characters are largely genetically controlled, and also it can be altered agronomically by wangling the crop environment and management factors. Growth attributes are the reflective process of effective utilization of resources in a better crop production environment. (Sharifi et al., 2009) had noted that when plant population is too high it encourages inter plant competition for resources and consequently the net photosynthesis would be affected due to less light penetrationin the crop canopy as well as increase in the competition for available nutrient resulting in poor growth of the plant.

\section{Pigeonpea growth attributes}

It was observed that Table no 1 Growth attributing character i.e. Plant height recorded non-significant values at the harvest stage. Plant height was substantially reduced as the row spacing was increased at all growth stages. The probable reason behind the increase in plant height $(\mathrm{cm})$ in narrow spacing may be due to more competition for light and $\mathrm{CO}_{2}$ between plants. These findings were in conformity with Yadav and Maurya (2012) who reported that closely spaced pigeonpea plants grow rapidly. Similar results were also reported by Lingaraju et al., (2008). In the narrow or dense planted pigeonpea, the numbers of branches were less than wider ones. The probable reason for more branching in wider planting geometry is the compensatory behaviour of the crop with adequate availability of occupying space, nutrients and moisture in the soil. These results are in conformity with the research findings concluded by Sonawane et al., (2011). Mean leaf area $\left(\mathrm{dm}^{2}\right)$ of pigeonpea per plant was increased substantially with the increased spacing at all observations except at harvest. Narrow planting geometry of pigeonpea $(90 \mathrm{~cm} \times 20 \mathrm{~cm})$ recorded lower number of leaves per plant as compare to wide geometry. Sharma and Guled (2012). also reported lower leaf area per plant with closely spaced pigeonpea plant than the plants with wide planting geometry. Significantly higher total dry matter accumulation (g) per plant was recorded in wider geometry (150 $\mathrm{cm})$. This was due to more number of leaves and leaf area per plant which might have increased photosynthates produced and its accumulation at a higher rate and quantity through process of plant metabolism which ultimately reflected in dry matter production. These findings are in agreement with Darshan (2000) who recorded higher accumulation of dry matter plant ${ }^{-1}$ with $120 \mathrm{~cm}$ x $15 \mathrm{~cm}$ spacing of pigeonpea crop.

\section{Pigeonpea yield}

Various growth and yield attributes were influenced due to different row spacings and plating geometries. They ultimately resulted into significant variation in pigeonpea yield per hectare. Pigeonpea seed yield $\left(\mathrm{kg} \mathrm{ha}^{-1}\right)$ was substantially higher under dense planting geometry i.e. sole pigeonpea $(90 \mathrm{~cm} \times 20 \mathrm{~cm}$ ) and it was reduced significantly with increase in spacing. Such type of advantages with dense planting geometry on pigeonpea yield was reported by Patil and Joshi (2002). Stalk yield $\left(\mathrm{kg} \mathrm{ha}^{-1}\right)$ and biological yield $\left(\mathrm{kg} \mathrm{ha}^{-1}\right)$ of pigeonpea showed similar trend as that of seed yield (kg ha-1) of pigeonpea. The higher Stalk yield $\left(\mathrm{kg} \mathrm{ha}^{-1}\right)$ and biological yield $(\mathrm{kg}$ $\mathrm{ha}^{-1}$ ) of pigeonpea was recorded in dense planting geometry i.e. sole pigeonpea $(90 \mathrm{~cm}$ x $20 \mathrm{~cm}$ ) and it was significantly higher than rest of the planting geometries. This might be attributed to higher growth rate of pigeonpea under dense planting, whose planting geometry helped for better light interception by crop coupled with high plant population as compared to other row spacings and planting geometries. 
Table.1 Effect of row spacing and planting geometry on growth attributes, and yield of pigeonpea at harvest as influenced by different treatments

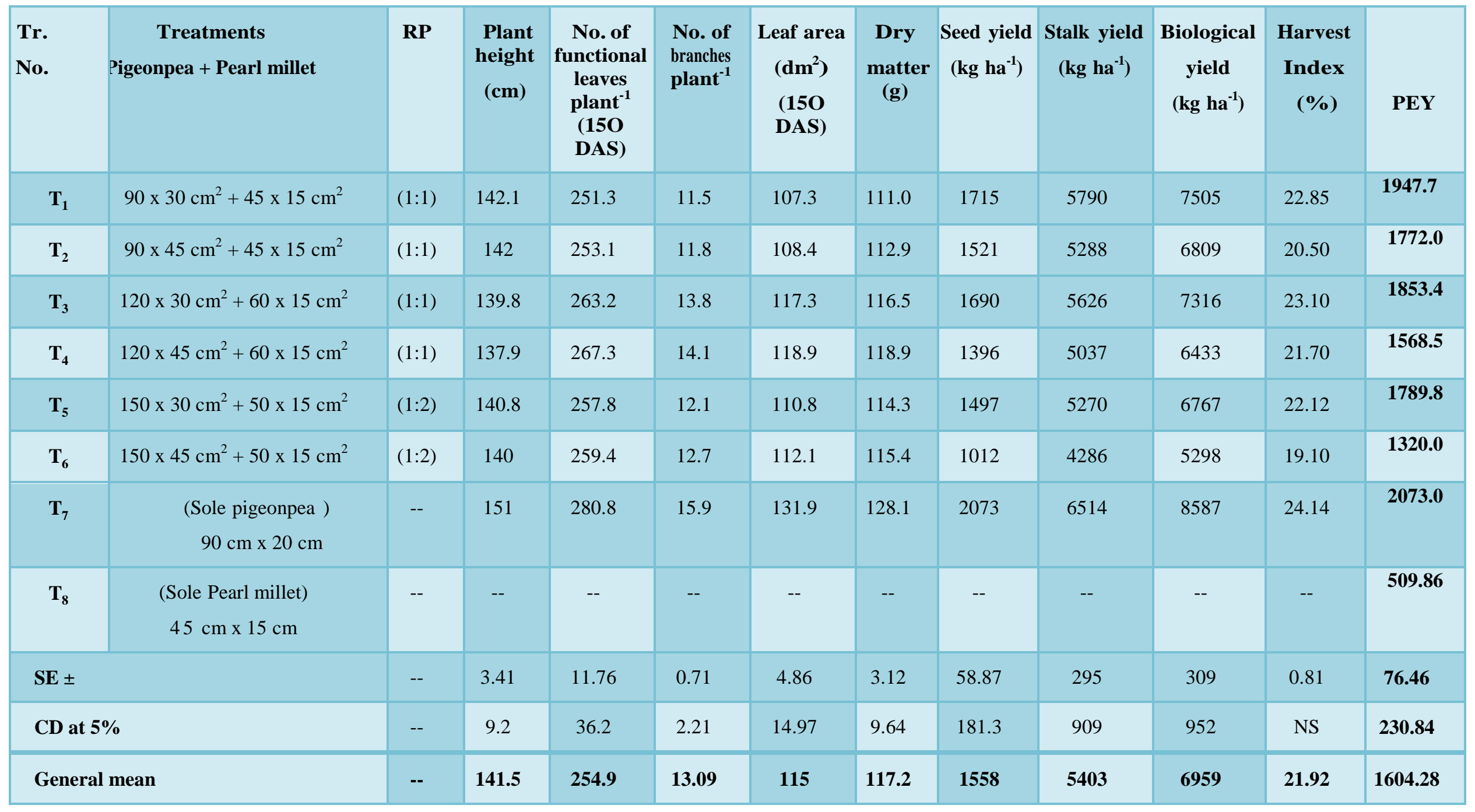


Table.2 Effect of row spacing and planting geometry on growth attributes, and yield of pearl millet at harvest as influenced by different treatments

\begin{tabular}{|c|c|c|c|c|c|c|c|c|c|c|c|}
\hline $\begin{array}{l}\text { Tr. } \\
\text { No. }\end{array}$ & $\begin{array}{c}\text { Treatments } \\
\text { Pigeonpea }+ \text { Pearl millet }\end{array}$ & $\mathbf{R P}$ & $\begin{array}{c}\text { Plant } \\
\text { height } \\
(\mathbf{c m})\end{array}$ & $\begin{array}{c}\text { No. of } \\
\text { function } \\
\text { al leaves } \\
\text { (90 DAS) }\end{array}$ & $\begin{array}{c}\text { No. of } \\
\text { tillers } \\
\text { per } \\
\text { plant }\end{array}$ & $\begin{array}{c}\text { Leaf } \\
\text { area } \\
\left(\mathbf{d m}^{2}\right) \\
(90 \\
\text { DAS })\end{array}$ & $\begin{array}{l}\text { Dry } \\
\text { matter } \\
(\mathrm{g})\end{array}$ & $\begin{array}{c}\text { Seed } \\
\text { yield } \\
\left(\mathrm{kg} \mathrm{ha}^{-1}\right)\end{array}$ & $\begin{array}{c}\text { Stalk } \\
\text { yield } \\
\left(\mathrm{kg} \mathrm{ha}^{-1}\right)\end{array}$ & $\begin{array}{c}\text { Biological } \\
\text { yield } \\
\left(\mathrm{kg} \mathrm{ha}^{-1}\right)\end{array}$ & $\begin{array}{c}\text { Harvest } \\
\text { Index } \\
(\%)\end{array}$ \\
\hline $\mathbf{T}_{1}$ & $90 \times 30 \mathrm{~cm}^{2}+45 \times 15 \mathrm{~cm}^{2}$ & $(1: 1)$ & 180.6 & 4.05 & 2.6 & 25.5 & 94.3 & 890 & 1976 & 2866 & 31.05 \\
\hline $\mathbf{T}_{\mathbf{2}}$ & $90 \times 45 \mathrm{~cm}^{2}+45 \times 15 \mathrm{~cm}^{2}$ & $(1: 1)$ & 176.3 & 4.12 & 2.7 & 26.8 & 96.44 & 960 & 2111 & 3073 & 31.27 \\
\hline $\mathbf{T}_{\mathbf{3}}$ & $120 \times 30 \mathrm{~cm}^{2}+60 \times 15 \mathrm{~cm}^{2}$ & $(1: 1)$ & 162.1 & 4.72 & 3.4 & 33.6 & 110.5 & 625 & 1400 & 2025 & 30.85 \\
\hline $\mathbf{T}_{4}$ & $120 \times 45 \mathrm{~cm}^{2}+60 \times 15 \mathrm{~cm}^{2}$ & $(1: 1)$ & 159.4 & 7.87 & 3.6 & 35.8 & 117.5 & 660 & 1478 & 2138 & 30.93 \\
\hline $\mathbf{T}_{5}$ & $150 \times 30 \mathrm{~cm}^{2}+50 \times 15 \mathrm{~cm}^{2}$ & $(1: 2)$ & 171.6 & 4.27 & 3.1 & 29.1 & 102.0 & 1120 & 2428 & 3548 & 31.56 \\
\hline $\mathbf{T}_{6}$ & $150 \times 45 \mathrm{~cm}^{2}+50 \times 15 \mathrm{~cm}^{2}$ & $(1: 2)$ & 168.1 & 4.42 & 3.2 & 31.2 & 104.9 & 1178 & 2540 & 3718 & 31.68 \\
\hline $\mathbf{T}_{7}$ & (Sole pigeonpea) $90 \mathrm{~cm} \mathrm{x} 20 \mathrm{~cm}$ & -- & -- & -- & -- & -- & -- & -- & -- & -- & - \\
\hline $\mathbf{T}_{8}$ & $\begin{array}{l}\text { (Sole Pearl millet) } \\
45 \mathrm{~cm} \times 15 \mathrm{~cm}\end{array}$ & -- & 186.1 & 3.67 & 2.4 & 22.3 & 88.03 & 1950 & 3935 & 5875 & 33.19 \\
\hline & $\mathbf{S E} \pm$ & -- & 4.50 & 0.17 & 0.12 & 0.12 & 2.88 & 49.59 & 154.5 & 202.1 & 0.92 \\
\hline & CD at $5 \%$ & -- & 13.86 & 0.59 & 0.37 & 0.37 & 8.87 & 152.8 & 476.1 & 622 & - \\
\hline & General mean & -- & 171.7 & 4.30 & 3.03 & 3.03 & 102.0 & 1054 & 2265 & 3318 & 31.50 \\
\hline
\end{tabular}


These results are in agreement with the research findings of Sonawane et al., (2011). Who reported that sole pigeonpea produced higher grain yield (18.07 $\left.\mathrm{q} \mathrm{ha}^{-1}\right)$ and straw yield (40.38 q ha ${ }^{-1}$ ).

\section{Performance of Bajra}

It was observed that Table no 2 the maximum Plant height $(186.1 \mathrm{~cm})$ During course of investigation, closer row spacing and dense planting geometry $(45 \mathrm{~cm} \times 15 \mathrm{~cm})$ i.e. sole pearl millet recorded maximum plant height till harvest of crop and it was followed by row proportion 1:1. This might be due to more competition for light and $\mathrm{CO} 2$ amongst the plants. These results are in conformity with the research findings concluded by Ramamoorthy et al., (2004).

Mean number of tillers per plant, Maximum number of functional leaves, leaf area $(\mathrm{dm} 2)$ and dry matter accumulation per plant, mean number of earhead of pearl millet was recorded higher under planting geometry (120 $\mathrm{cm} \times 45 \mathrm{~cm}+60 \mathrm{~cm} \times 15 \mathrm{~cm}$ ) of pigeonpea followed by planting geometry $(120 \mathrm{~cm} \times 30$ $\mathrm{cm}+60 \mathrm{~cm} \times 15 \mathrm{~cm}$ ). This might be due to less competition for nearer rows of pearl millet to soil moisture and space for leaf proliferation. Number of functional leaves, leaf area $(\mathrm{dm} 2)$ and dry matter (g) accumulation per plant were observed to decline at the maturation period because of leaf senescence, yellowing and leaf fall. Rakesh kumar, (2004) Venkateswarlu et al., (1979) Pearl millet accumulated comparatively higher dry matter plant" under different strip cropping systems up to 50 DAS than those of sole and inter cropping treatments. Anjaneyulu et al., (1982) also reported that highest dry weight was recorded in intercropping system as compared to sole stand.

Higher pearl millet seed yield $\left(\mathrm{kg} \mathrm{ha}^{-1}\right)$, straw yield $\left(\mathrm{kg} \mathrm{ha}^{-1}\right)$ a biological yield $\left(\mathrm{kg} \mathrm{ha}^{-1}\right)$ and harvest index $(\%)$ is reported in were recorded in sole planting of pearl millet $(45 \mathrm{~cm} \mathrm{x} 15$ $\mathrm{cm})$. Similar findings were also reported by Anjaneyulu (1982).

Based on the result findings of research investigation, the conclusions may be drawn. Thus, it can be concluded that intercropping of pigeonpea with Bajra the higher growth and yield is obtained in sole pigeonpea i.e., $\mathrm{T}_{7}$ (Sole pigeonpea ) $90 \mathrm{~cm} \times 20 \mathrm{~cm}$ and $\mathrm{T}_{8}$ (Sole Bajra) $45 \times 15 \mathrm{~cm}$ where highest pigeonpea equivalent yield is recorded in $\mathrm{T}_{7}(2073.0 \mathrm{~kg}$ $\left.\mathrm{ha}^{-1}\right)$ i.e. sole pigeonpea $(90 \mathrm{~cm} \times 20 \mathrm{~cm})$ which was at par with the intercropping treatments $\mathrm{T}_{1}(90 \mathrm{~cm} \times 30 \mathrm{~cm}+45 \mathrm{~cm} \times 15$ $\mathrm{cm}$ - $\left.1947.7 \mathrm{~kg} \mathrm{ha}{ }^{-1}\right)$ i.e. having row proportion $1: 1$ and $\mathrm{T}_{3}(120 \mathrm{~cm} \times 30 \mathrm{~cm}+60$ $\left.\mathrm{cm} \times 15 \mathrm{~cm}-1853.4 \mathrm{~kg} \mathrm{ha}^{-1}\right)$ i.e. having row proportion $1: 1$. Hence, they may be termed as optimum for cultivation of pigeonpea Bajra intercropping system.

\section{References}

Anjaneyulu, V. R. 1982. Intercropping of hybrid bajra (Pennisetum typhoides (Burmf. F.) stapf and C.E. Hubb.) with mung (Vigna radiata (L.) Wilczek) under rainfed conditions. Ph.D. Thesis, Division of Agronomy, IARI, New Delhi.

Darshan, R. 2008. Intercropping of pigeonpea with sesame cultivars under different planting geometry and row proportions in northern transition zone of Karnataka. M.Sc. (Agri.) Thesis, Department of Agronomy, UAS, Dharwad (Karnataka), India.

Lingaraju, B. S., S. B. Marer and S. S. Chandrashekar. 2008. Studies on intercropping of maize and pigeonpea under rainfed conditions in northern transitional zone of Karnataka. Karnataka Journal of Agricultural Science. 21(3): 1-3.

Rakesh kumar, 2004. Performance of 
intercropping and stripcroppins systems of pearl millet legume association. Thesis Submitted to Choudhiary Charan Singh Haryana Agricultural University, department of agronomy HISAR.

Ramamoorthy, K., A. Christopher Lourduraj, S. Alagudurai, O.S. Kandasamy and V. Murugappan. 2004. Intercropping pigeonpea (Cajanus cajan) in fingermillet (Elusine coracana) on productivity and soil fertility under rainfed condition. Indian Journal of Agronomy. 49(1), 28-30.

Rao, M. R. and W. Willey, 1983. Effect of pigeon pea plant population and row arrangement in sorghum / pigeon pea intercropping. Field Crops Research. 7:203-212.

Reddy, A. P. K., V. S. Selvam, G. N., S. N. Rao and M. S. S. Rajan. 1993. Intercropping in late rainy season pigeonpea (Cajanus cajan) under rainfed condition. Indian Journal of Agronomy. 38(2), 232-235.

Sharif, R.S., Sedghi, M and Gholipouri, A. 2009 Effect of plant population density and yield attributes of maize hybrids. Res. J. Biol. Sci., 4(4): 375-379

Sharma, A., M. B. Guled. 2009. Effect of set farrow cultivation in pigeonpea + pearl millet and pigeonpeat sesame intercropping systems in shollow black soil under rainfed conditions. Karnataka journal Agricultural science. 24 (5) (643-650).

Sonawane, D. A., T. M. Bahale and N. D. Dalavi. 2011. Evaluation of pigeonpea based intercropping systems under scarcity condition of Northern Maharashtra. JNKVV Research Journal. 45(1): 81-84.

Venkateswarlu, J., Sanghi, N. K., Rao, M. B. and Rao, C. H. 1979. Maximizing production in a sorghum/ pigeonpea system in the semi- arid tropics. p. 3034. In Willey, R. W (eds), Proc. Inter. Work Shop on Intercropping. 10-13 Jan. 1978. ICRISAT, Hyderabad, India

Willey, R. W., Rao, M.R. and Natrajan, M. 1980. Traditional cropping system with pigeon pea and their improvement. In Proc. Inte. Workshop pigeonpea, December 15-19, 1980, ICRISAT, Patancheru, pp 11-25

Yadav, P. S. and B. M. Maurya. 2012. Assessment of productivity and economics of various soybean + pigeonpea intercropping system under rainfed condition of Rewa region of Madhya Pradesh. JNKVV Research Journal. 46(3): 355-359.

\section{How to cite this article:}

Pandit, S. G., N. G. Khurade, V. R. More and Jagtap, M. P. 2020. Response of Pigeon Pea + Bajra Intercropping Systems under Variable Crop Geometry and Plant Population Level Under Rainfed Condition. Int.J.Curr.Microbiol.App.Sci. 9(02): 1673-1679. doi: https://doi.org/10.20546/ijcmas.2020.902.193 